\title{
The resistance of hazel (Corylus avellana L.) to hazelnut weevil (Curculio nucum L., Coleoptera, Curculionidae). Part I. Evaluation of the resistance of several cultivars*
}

\author{
ZDZISLAW PISKORNIK
}

Laboratory of Plant Physiology, Faculty of Horticulture, Agricultural University, Al. 29 Listopada 54, 31-425 Kraków, Poland

(Received: March 11, 1988)

\begin{abstract}
In the course of 5 year investigations (1981-1985) considerable differences were found in the resistance of 24 hazel cultivars to hazelnut weevil (Curculio nucum L.). The resistance was determined on the basis of the percentage of nuts damaged by larvae in the total yield. Six classes of resistance were established, from class I - very resistant cultivars, to class VI - very susceptible cultivars. In feeding experiments a positive correlation, significant at the $1 \%$ and $5 \%$ level was found between the frequency of beetle feeding on hazel fruitlets during the time of oviposition (July), and the class of resistance of cultivars; a negative correlation between these parameters was found in August, i.e. during hatching and development of larvae in the nuts. In July the beetles fed more readily and more frequently on nuts of susceptible cultivars, whereas they avoided them in August, i.e. in the period when larvae developed in many fruits of these cultivars.
\end{abstract}

\section{INTRODUCTION}

Hazelnut weevil (Curculio nucum L.) is the main pest of hazel trees (Corylus avellana L.) cultivated in Europe and in the Near East. In some regions of the world, e.g. in America, Australia, and New Zealand this pest does not occur. Hazelnut weevil is a beetle of the weevil family (Curculionidae) feeding on leaves and subsequently on hazelnut fruitlets. Beetles $8 \mathrm{~mm}$ long usually appear at the end of May or in the first decade of June. Oviposition begins in the first decade of July ( $\mathrm{E}$ s s k a, 1973). Eggs are laid inside hazelnut fruitlets just below the soft pericarp, on the surface of the endosperm tissue which fills the growing nuts at that time. The incubation period lasts 6-13 days ( $\mathrm{K}$ ę s ka, 1973) or longer, and hatched larvae start to feed on the endosperm tissue and later on the growing cotyledons of the nuts. The larvae complete their development within 33-38

* This study was partially financed by the Polish Academy of Sciences, Project no. MR II/7.2.2.1. 
days and leave the nuts through a hole of about $2 \mathrm{~mm}$ in diameter bored in the lignified pericarp (shell). The larvae complete their hibernation in the soil usually at a depth of $10-20 \mathrm{~cm}$ within $1-2$ years. Sometimes the diapause lasts up to 3 years ( $\mathrm{Leqska,1973).}$

At present, there is a growing interest in cultivation of hazel in Poland. Consequently, it is necessary to develop efficient methods for protection of hazel plantations against the main pest. Until now, a few papers have been published on the chemical methods of hazel protection (Kęska, 1973; Suski, 1986), but information on utilization of the natural resistance potential of the hazel against the hazelnut weevil is not available.

Several years long observations made in southern Poland showed that hazel cultivars manifest differentiated susceptibility to the pest. The present paper is aimed at evaluating the resistance of 24 cultivars of hazel to hazelnut weevil during a 5 year investigation period.

\section{MATERIAL AND METHODS}

The resistance of hazel to hazelnut weevil was investigated during 1981-1985 on a plantation of the Hazel Breeding Station in Cracow, Poland. Hazel trees, 10-15 years old, grew on loessial soil on a slope with a northern exposure and $12^{\circ}$ inclination. No phytosanitary treatment was used on the plantation during the investigation period. Basic mineral nutrients were applied in the following quantities per tree: $0.77 \mathrm{~kg} \mathrm{~N} ; 0.09 \mathrm{~kg} \mathrm{P}$ and $0.18 \mathrm{~kg} \mathrm{~K}$.

The plant material consisted of 24 cultivars of hazel, among them 6 old ones cultivated in Poland for many years, and 18 new cultivars (Table 1). Each cultivar was represented by 4 trees, each treated as one replication. Cultivars were distributed on the plantation randomly. Four samples of 100 nuts, and in the years of poor yielding of 50 nuts were collected from the yield of every tree and the percentage of nuts damaged by the weevil larvae was determined. In order to establish the level of resistance of each cultivar to the pest the following scale was applied:

class I - resistant cultivars (0-2\% of damaged nuts),

class II - fairly resistant cultivars ( 2.1 to $5 \%$ of damaged nuts),

class III - moderately resistant cultivars (5.1 to $10 \%$ of damaged nuts),

class IV - fairly susceptible cultivars (10.1 to $20 \%$ of damaged nuts),

class V - susceptible cultivars (20.1 to $50 \%$ of damaged nuts),

class VI - very susceptible cultivars (over $50 \%$ of damaged nuts).

Laboratory experiments on the food preference of the weevil beetles were carried out in 1983 and 1984 in two periods:

1 - in the period of intensive oviposition, that is, in the first decade of July 1983 , and in the second decade of July 1984;

2 - in the period of larvae hatching and development in the growing nuts, that is, in the first decade of August 1983, and in the second decade of August 1984. 


\section{Table 1}

List of hazel cultivars used for evaluation of resistance to hazelnut weevil and for experiments on food preference of the pest beetles. (Sign + denotes cultivar used for experiment on food preference)

\begin{tabular}{|c|c|c|c|c|c|}
\hline \multirow{3}{*}{ No. } & \multirow{3}{*}{$\begin{array}{l}\text { Hazel cultivar } \\
\text { (Polish, English or } \\
\text { German name) }\end{array}$} & \multicolumn{4}{|c|}{ Feeding experiments } \\
\hline & & \multicolumn{2}{|c|}{$\begin{array}{l}\text { period of } \\
\text { oviposition }\end{array}$} & \multicolumn{2}{|c|}{$\begin{array}{l}\text { period of larvae } \\
\text { hatching and de- } \\
\text { velopment }\end{array}$} \\
\hline & & 1983 & 1984 & 1983 & 1984 \\
\hline \multicolumn{6}{|c|}{ Old cultivars } \\
\hline \multirow[t]{2}{*}{1} & Wonder from & & & & \\
\hline & Bollwiller & - & + & - & + \\
\hline 2 & Gubener Zellernuss & - & - & - & - \\
\hline 3 & Catalan & + & + & + & + \\
\hline 4 & Hall's Giant & + & + & + & + \\
\hline 5 & Truchsess Zellernuss & - & + & - & + \\
\hline 6 & Webb's Prize Nut & + & + & + & + \\
\hline \multicolumn{6}{|c|}{ New cultivars } \\
\hline 7 & Bomb & + & + & + & + \\
\hline 8 & Frango-I & + & + & + & + \\
\hline 9 & Frango-II & + & + & + & + \\
\hline 10 & Frango-III & - & + & - & + \\
\hline 11 & Frango-IV & - & - & - & - \\
\hline 12 & Justovski Late & + & + & + & + \\
\hline 13 & Carol & - & + & - & + \\
\hline 14 & Cracow & + & + & + & + \\
\hline 15 & Volski-Round & - & - & - & - \\
\hline 16 & Lenka-I & - & - & - & - \\
\hline 17 & Lenka-II & + & + & + & + \\
\hline 18 & Lenka-III & + & + & + & + \\
\hline 19 & Lenka-IV & + & + & + & + \\
\hline 20 & Marie & + & + & + & + \\
\hline 21 & Earliest & + & + & + & + \\
\hline 22 & Novoviejski & + & + & + & + \\
\hline 23 & Starovolski & - & + & - & + \\
\hline 24 & Warsaw-Red & + & + & + & + \\
\hline \multicolumn{2}{|c|}{$\begin{array}{l}\text { Number of cultivars used } \\
\text { for feeding experiments }\end{array}$} & 15 & 20 & 15 & 20 \\
\hline
\end{tabular}

The cultivars used for these experiments are listed in Table 1. The method of long term feeding was used in the experiments. Nut fruitlets, 6 of each cultivar, were collected and placed randomly on a plastic tray $50 \times 60 \times 7 \mathrm{~cm}$ in size, lined with moistened filter paper and covered with a glass plate. Before the experiment was started, 10 beetles starved in light at a temperature $20-22^{\circ} \mathrm{C}$ for the preceding $48 \mathrm{~h}$, were let onto the tray. The feeding period of the beetles on nut fruitlets lasted for $48 \mathrm{~h}$ at a temperature of $23 \pm 1^{\circ} \mathrm{C}$. Subsequently the 
beetles were removed from the trays and the number of punctures on the pericarp of nuts resulting from pest feeding was counted. Conclusions were drawn on this basis as to the food preference of beetles with respect to particular cultivars. The experiments in 1983 were carried out in 5 replications. In the following year the method was slightly modified; the number of beetles let onto the trays was increased to 20 , with a simultaneous increase in the number of fruitlets of each cultivar as well as the number of replications to 8 .

Correlation between the class of resistance of cultivars used for experiments and the number of punctures on the pericarp which was the adopted measure of frequency of pest feeding on nut fruitlets, was counted. The class of hazel cultivar resistance to the pest was determined basing upon the results obtained in the preceding vegetation season.

\section{RESULTS}

The vegetative seasons varied considerably in the years 1981 to 1985 in respect to weather conditions, this influencing the hazelnut yield, the weevil beetle population, as well as the degree of hazelnut yield injury caused by the pest larvae. The years 1981 and 1983 were not favourable for hazel cropping, in the other years the yields were on an average level. Tree and arthropod phenology also slightly differed from year to year.

Table 2 shows the results of a 5 year evaluation of resistance. This points to considerable differences in the resistance of particular cultivars to the pest. Wonder from Bollwiller and Hall's Giant cultivars remained untouched by hazelnut weevil larvae and nuts of the cultivar Lenka-II were damaged only sporadically. Three cultivars: Marie, Carol, and Lenka-IV demonstrated considerable resistance to the pest, though in some years some of them revealed a higher degree of yield damage; these cultivars were classified in class II. In class III, cultivars of moderate resistance, represented by 5 cultivars, showed a greater susceptibility to the pest, and 2 cultivars were in the 5 year investigation period classified to three classes of resistance (to classes II, III and IV). This was the cultivar Volski-Round and a highly fruitbearing red-leafy cultivar Warsaw-Red. The greatest differences in the degree of yield loss were found in the valuable and popular in Poland cultivar Catalan - classified in class IV, hence a class of cultivars fairly susceptible to the pest. In 1982 this cultivar was classified in class II, and in 1984 in class V. A bit smaller differences in the damage level were found in the other three cultivars from class IV. Seven cultivars were considered susceptible (class V), however, only in one of them, i.e. in Bomb were the differences in the degree of yield damage quite considerable, ranging from class III in 1981, class IV in 1982 and 1983 to class V in 1984 and 1985. Cultivars Novoviejski and Earliest, which revealed high susceptibility to the pest during the whole investigation period were classified in class VI. 
Table 2

The resistance of 24 hazel cultivars to hazelnut weevil (Curculio nucum L.) estimated on the basis of percentage of hazelnuts damaged by larvae in the total yield in the years 1981-1985. (Order of cultivars according to the increasing mean values of damaged hazelnuts in the total yield)

\begin{tabular}{|c|c|c|c|c|c|c|c|c|c|c|c|c|c|}
\hline \multirow{2}{*}{$\begin{array}{l}\text { Class }^{1} \text { of } \\
\text { resistance }\end{array}$} & \multirow{2}{*}{ No. } & \multirow{2}{*}{ Cultivar } & \multicolumn{2}{|c|}{1981} & \multicolumn{2}{|c|}{1982} & \multicolumn{2}{|c|}{1983} & \multicolumn{2}{|c|}{1984} & \multicolumn{2}{|c|}{1985} & \multirow{2}{*}{$\begin{array}{c}\text { Mean from } \\
\text { the years } \\
1981-1985 \\
\pm S E\end{array}$} \\
\hline & & & $\%^{2}$ & class $^{3}$ & $\%$ & class & $\%$ & class & $\%$ & class & $\%$ & class & \\
\hline I & 1 & Wonder from Bollwiller & 0 & I & 0 & I & 0 & I & 0 & I & 0 & I & 0 \\
\hline \multirow[t]{2}{*}{ Resistant } & 2 & Hall's Giant & 0 & I & 0 & I & 0 & I & 0 & I & 0 & I & 0 \\
\hline & 3 & Lenka-II & 1.0 & I & 0 & I & 0 & I & 0 & I & 0.5 & I & $0.3 \pm 0.1$ \\
\hline & 4 & Marie & 4.0 & II & 0 & I & 2.8 & II & 3.0 & II & 2.3 & II & $2.5 \pm 0.4$ \\
\hline \multirow{2}{*}{ Fairly resistant } & 5 & Lenka-IV & 3.0 & II & 2.5 & II & 4.0 & II & 5.0 & II & 4.5 & II & $3.8 \pm 0.4$ \\
\hline & 6 & Carol & 3.5 & II & 3.3 & II & 1.3 & I & 4.8 & II & 6.8 & III & $3.9 \pm 0.6$ \\
\hline III & 7 & Lenka-III & 4.0 & II & 3.0 & II & 2.5 & II & 7.8 & III & 8.8 & III & $5.2 \pm 0.7$ \\
\hline \multirow{4}{*}{$\begin{array}{l}\text { Moderately resis- } \\
\operatorname{tant}\end{array}$} & 8 & Gubener Zellernuss & 13.0 & IV & 5.3 & III & 5.3 & III & 9.5 & III & 9.5 & III & $8.5 \pm 0.8$ \\
\hline & 9 & Warsaw-Red & 3.5 & II & 6.3 & III & 9.5 & III & 12.8 & IV & 12.5 & IV & $9.1 \pm 1.1$ \\
\hline & 10 & Webb's Prize Nut & 10.5 & IV & 7.5 & III & 6.0 & III & 11.0 & IV & 11.8 & IV & $9.4 \pm 0.6$ \\
\hline & 11 & Volski-Round & 2.5 & II & 7.5 & III & 8.5 & III & 19.0 & IV & 10.8 & IV & $9.7 \pm 1.4$ \\
\hline IV & 12 & Frango-IV & 7.0 & III & 7.3 & III & 9.0 & III & 23.8 & V & 15.8 & IV & $12.6 \pm 1.6$ \\
\hline \multirow[t]{3}{*}{ Fairly susceptible } & 13 & Catalan & 5.5 & III & 3.0 & II & 5.8 & III & 38.0 & $\mathrm{~V}$ & 14.0 & IV & $13.3 \pm 3.1$ \\
\hline & 14 & Lenka-I & 6.5 & III & 18.0 & IV & 18.0 & IV & 19.5 & IV & 18.0 & IV & $16.0 \pm 1.4$ \\
\hline & 15 & Frango-II & 15.0 & IV & 15.5 & IV & 19.3 & IV & 18.8 & IV & 20.3 & $\mathrm{~V}$ & $17.8 \pm 1.0$ \\
\hline $\mathrm{V}$ & 16 & Bomb & 5.5 & III & 18.5 & IV & 18.5 & IV & 48.0 & V & 21.0 & V & $22.3 \pm 3.3$ \\
\hline \multirow[t]{6}{*}{ Susceptible } & 17 & Frango-I & 26.0 & $\mathrm{~V}$ & 10.3 & IV & 18.3 & IV & 25.5 & $\mathrm{~V}$ & 32.0 & V & $22.4 \pm 2.0$ \\
\hline & 18 & Justovski & 51.0 & VI & 22.8 & $\mathrm{~V}$ & 29.0 & $\mathrm{~V}$ & 13.5 & IV & 30.0 & V & $28.5 \pm 3.4$ \\
\hline & 19 & Truchsess Zellernuss & 14.0 & IV & 31.7 & $\mathrm{~V}$ & 36.5 & $\mathrm{~V}$ & 37.5 & $\mathrm{~V}$ & 31.5 & V & $30.3 \pm 2.2$ \\
\hline & 20 & Frango-III & 41.0 & $\mathrm{~V}$ & 31.7 & $\mathrm{~V}$ & 19.5 & IV & 45.5 & V & 26.0 & $\mathrm{~V}$ & $32.8 \pm 2.5$ \\
\hline & 21 & Starovolski & 19.5 & IV & 29.0 & V & 37.8 & V & 60.0 & VI & 52.8 & VI & $39.8 \pm 3.7$ \\
\hline & 22 & Cracow & 22.0 & $\mathrm{~V}$ & 35.3 & $\mathrm{~V}$ & 42.0 & $\mathrm{~V}$ & 60.8 & VI & 72.8 & VI & $46.6 \pm 4.3$ \\
\hline VI & 23 & Novoviejski & 55.0 & VI & 20.8 & $\mathrm{~V}$ & 75.6 & VI & 78.8 & VI & 78.0 & VI & $61.7 \pm 5.4$ \\
\hline Very susceptible & 24 & Earliest & 88.0 & VI & 56.5 & VI & 85.0 & VI & 86.3 & VI & 83.0 & VI & $79.8 \pm 3.2$ \\
\hline
\end{tabular}

${ }^{1}$ Explanations - see "Material and methods"; ${ }^{2} \%$ of damaged nuts; ${ }^{3}$ Class, of resistance in the given year 
The results of experiments on weevil beetle food preference, performed in the period of intensive oviposition, are presented in Table 3. In both years, a close relation was found between the feeding frequency of the pest beetles on young nuts, and the class of resistance of the cultivars used in experiments. The pest attacked mostly the fruitlets of the most susceptible cultivars, whereas, it fed less frequently on more resistant ones. The correlation coefficients 0.963 in 1983 and 0.802 in 1984 were significant at the 1 and 5\% levels, respectively (Table 3).

\section{Table 3}

The relation between the class of hazel cultivar resistance to hazelnut weevil and frequency of beetle feeding on hazel fruitlets during the oviposition period (Ist decade of July, 1983, and IInd decade of July, 1984)

\begin{tabular}{|c|c|c|c|c|c|c|}
\hline \multirow[t]{2}{*}{$\begin{array}{l}\text { Class of } \\
\text { resistance }\end{array}$} & \multicolumn{2}{|c|}{$\begin{array}{l}\text { No. of cultivars } \\
\text { in the given class }\end{array}$} & \multicolumn{2}{|c|}{$\begin{array}{l}\text { Mean number of } \\
\text { punctures on the } \\
\text { hazelnut pericarp } \\
\text { during } 48 \mathrm{~h} \text { feeding } \\
\text { period }\end{array}$} & \multicolumn{2}{|c|}{$\begin{array}{c}\text { Correlation } \\
\text { coefficient }\end{array}$} \\
\hline & 1983 & 1984 & 1983 & 1984 & 1983 & 1984 \\
\hline I & 3 & 4 & 4.6 & 4.4 & $r=0.966$ & $r=0.802$ \\
\hline II & 3 & 3 & 7.2 & 5.1 & signifi- & signifi- \\
\hline III & 2 & 3 & 6.6 & 7.7 & cant at & cant at \\
\hline IV & 3 & 4 & 8.4 & 7.2 & $1 \%$ level & $5 \%$ level \\
\hline V & 3 & 4 & 10.1 & 10.3 & & \\
\hline VI & 1 & 2 & 11.8 & 7.7 & & \\
\hline
\end{tabular}

Table 4

The relation between the class of hazel cultivar resistance to hazelnut weevil and frequency of beetle feeding on growing nuts during the period of hatching and larvae development (Ist decade of August, 1983, and IInd decade of August, 1984)

\begin{tabular}{|c|c|c|c|c|c|c|}
\hline \multirow[t]{2}{*}{$\begin{array}{l}\text { Class of } \\
\text { resistance }\end{array}$} & \multicolumn{2}{|c|}{$\begin{array}{l}\text { Number of cultivars } \\
\text { in the given class }\end{array}$} & \multicolumn{2}{|c|}{$\begin{array}{l}\text { Mean number of } \\
\text { punctures on the } \\
\text { hazelnut pericarp } \\
\text { during } 48 \mathrm{~h} \text { feeding } \\
\text { period }\end{array}$} & \multicolumn{2}{|c|}{$\begin{array}{c}\text { Correlation } \\
\text { coefficient }\end{array}$} \\
\hline & 1983 & 1984 & 1983 & 1984 & 1983 & 1984 \\
\hline I & 3 & 4 & 4.7 & 5.5 & $r=-0.627$ & $r=-0.758$ \\
\hline II & 3 & 3 & 7.0 & 4.7 & signifi- & signifi- \\
\hline III & 2 & 3 & 6.6 & 4.3 & cant at & cant at \\
\hline IV & 3 & 4 & 4.6 & 5.9 & $10 \%$ level & $5 \%$ level \\
\hline V & 3 & 4 & 5.5 & 3.1 & & \\
\hline VI & 1 & 2 & 0.8 & 1.6 & & \\
\hline
\end{tabular}


Similar experiments carried out in the period of larvae development in the nuts (Table 4) showed that the feeding frequency of beetles of the pest was much lower on nuts of very susceptible, susceptible and fairly susceptible cultivars (classes VI, V and IV), whereas on nuts of more resistant cultivars (classes I, II and III) the feeding frequency was similar as in July, i.e. during oviposition. As a result, the correlation coefficient between the class of resistance and number of punctures on the pericarp caused by the beetles had a negative value and was -0.636 and -0.758 in 1983 and 1984 , respectively, these being significant at the $10 \%$ level in the first year of investigation and $5 \%$ in the second one.

\section{DISCUSSION}

So far, no reports have been published on the resistance of various hazel cultivars to the hazelnut weevil. Only Bardia (1959) and Łęska (1973) mentioned a few cultivars susceptible and more resistant to this pest. At present, control of hazelnut weevil is limited only to application of pesticides (De Rosa, 1956; Suski, 1986).

The results of 5 year investigations on the resistance of 24 hazel cultivars to this pest show that nuts of certain cultivars are not damaged by larvae of the weevil, or if attacked, injury is negligible. A few cultivars, on the other hand, are greatly injured, e.g. in the cultivar Earliest the damage of nuts in the total yield in four years exceeded $80 \%$. The majority of cultivars showed intermediate resistance to the pest. Out of the 24 cultivars, 11 can be considered fairly resistant to hazelnut weevil, i.e. loss of yield did not exceed $10 \%$.

Experiments on the food preference of weevil beetles showed in the period of intensive oviposition a much higher feeding frequency on fruitlets of those cultivars in which a higher percentage of damaged nuts was found in the total yield; whereas, on cultivars where nuts were damaged to a lower degree by larvae the feeding frequency was lower. Basing upon this one may suppose that a certain quality of food, the presence or absence of certain compounds in the food, which may prevent the arthropod from feeding or laying eggs in the fruitlets, is decisive for the choice of food and place of oviposition. If this supposition is true, then one of the possible mechanism of resistance of certain hazel cultivars to the weevil bears the nature of antibiosis (Painter, 1951). Since during the oviposition period the growing nuts are almost completely filled with a white endosperm tissue, chemical analysis of this tissue to verify this supposition is necessary.

At a later stage of development of hazelnuts, an intensive development of the embryo, especially of its cotyledons, takes place inside the pericarp, whereas the endosperm tissue undergoes hydrolysis and disappears. A mature hazel fruit is a nonendospermal nut (Strasburger, 1967). By hatching period, the larvae have the cotyledon tissue at their disposal as food. In terms of chemical composition, it differs greatly from the food the pest beetles fed on. 
Experiments on the food preference of beetles carried out in the first half of August revealed that insects still pierced the hardening pericarp of growing nuts. The feeding frequency of hazelnut weevils on nuts of more resistant cultivars was similar as in July, whereas was many times lower on nuts of susceptible cultivars (Table 4). Most probably the beetles avoided feeding on nuts in which larvae were developing. This is indicated also by the negative value of the correlation coefficient between the class of cultivar resistance and the number of punctures in the pericarp caused by feeding beetles. These insects possibly recognized the nuts occupied by larvae. If this is true, it may indicate the existence of a signal received by beetles, which discourages the pest from feeding on nuts inhabited by larvae. This nature of the putative signal is in the case of hazelnuts unknown, but may have a pheromone character (Karls on, 1970). Chemical cues emitted from a host tissue also may serve as signals of egg or larval occupancy (Rothschild and Schoonhoven, 1977; Saxena and Basit, 1982; Mitchell and Heath, 1985). Prokopy (1972) has found that the apple maggot fly, Rhagoletis pomonella (Walsh), deposits a pheromone after oviposition that deters conspecifics from laying additional eggs in the same host fruit. In some cases a pest responds to wound exudates of the host tissue in discriminating against fruits or tissues already infested with conspecifics (Roitberg and Prokopy, 1982; cit. by Butkewich et al., 1987). On the other hand within some species, e.g. plum curculio, observed in nature or in laboratory choice tests, female beetles oviposited repeatedly into the same fruit (Owens et al., 1982; Butkewich et al., 1987), but with increasing egg density per fruit, larval survivorship progressively declined (Butkewich et al., 1987).

On the other hand, a different resistance mechanism proposed by $\mathrm{Painter}$ (1951), i.e. non-preference, may also function within Corylus avellana species and it should be considered in further investigations.

The presented investigations were carried out on a hazel plantation on which over 40 cultivars were growing. From these, 24 cultivars were chosen for observations. Hazelnut weevil beetles had at their disposal then a wide possibility of choosing a suitable plant as a host and suitable place for oviposition. It is necessary to carry out similar observations on a plantation where only a small of hazel cultivars resistant to the pest are cultured. In such a case the resistance of cultivars classified in classes I and II can be verified. It should also be examined if the lignification rate of the pericarp and its thickness and hardness influence the resistance of hazel cultivars to hazelnut weevil.

\section{REFERENCES}

Bardia B. R., 1959. "El diablo" (Balaninus nucum L.) del aveliano en Cataluna. Rev. Inst. Agric.

Catal. 108: 122-125.

Butkewich S. L., Prokopy R. J., Green T. A., 1987. Discrimination of occupied host fruit by plum curculio females (Coleoptera, Curculionidae). J. Chem. Ecol. 13: 1833-1841.

De Rosa M., 1956. Il balanino delle nocciole. Ital. Agric. 93: 931-936. 
Karlson P., 1970. Terpenoids in insects. [In:] Natural substances formed biologically from mevalonic acid. T. W. Goodwin (ed.), Academic Press, London and New York, pp. 145-156.

Lęska W., 1973. Badania nad biologią słonkowca orzechowca - Curculio (Balaninus) nucum L. (Col., Curculionidae) i jego niszczenie. Pol. Pismo Entomol. 43: 861-873.

Mitchell E. R., Heath R. R., 1985. Influence of Amaranthus hybridus (L.) allelochemicals on oviposition behavior of Spodoptera exiqua and S. eridania (Lepidoptera: Noctuidae). J. Chem. Ecol. 11: 609-617.

Owens E. D., Hauschild K. J., Hubbell G. L., Prok opy R. J., 1982. Diurnal behavior of plum curculio (Coleoptera: Curculionidae) adults within host trees in nature. Ann. Entomol. Soc. Am. 75: 357-362.

Painter R. H., 1951. Insect resistance in crop plants. II. The mechanisms of resistance. Mc Millan Co., New York, pp. 23-83.

Prokopy R. J., 1972. Evidence for a marking pheromone deterring repeated oviposition in apple maggot flies. Environ. Entomol. 1: 326-332.

Roitberg B. D., Prok opy R. J., 1982. Resource assessment by adult and larval codling moths. N.Y. Entomol. Soc. 90: 258-265.

Rothschild M., Schoonhoven L. M., 1977. Assessment of egg load by Pieris brassicae (Lepidoptera: Pieridae). Nature, 266: 352-355.

Saxena K. N., Basit A., 1982. Inhibition of oviposition by volatiles of certain plants and chemicals in the leafhopper Amrasca devastans (Distant). J. Chem. Ecol. 8: 329-339.

Strasburger E., 1967. Botanika. PWRiL, Warszawa.

Suski Z. W., 1986. Szkodniki leszczyny i ich zwalczanie. Pr. Inst. Sad. Kwiac., Ser. C, Biul. Inf. 2: 26-29.

Odporność leszczyny (Corylus avellana L.) na słonkowca orzechowca (Curculio nucum L.). Część I. Określenie odporności 24 odmian leszczyny na szkodnika w latach 1981-1985

\section{Streszczenie}

W 5-letnich badaniach przeprowadzonych w latach 1981-1985 stwierdzono znaczne różnice w odporności 24 odmian leszczyny na słonkowca orzechowca. Odporność oznaczano na podstawie procentu orzechów uszkodzonych przez larwy szkodnika w plonie ogólnym. Przyjęto 6 klas odporności, od klasy I - odmiany odporne, do klasy VI - odmiany bardzo wrażliwe. W dwuletnich doświadczeniach laboratoryjnych nad preferencją pokarmową chrząszczy słonkowca orzechowca stwierdzono dodatnią korelację, istotną przy poziomie 1 i $5 \%$, między częstotliwością żerowania chrząszczy na zawiązkach orzechów w okresie składania jaj (lipiec) a klasą odporności odmian oraz ujemną korelację między tymi parametrami w sierpniu, tj. $w$ okresie wylęgania się $\mathrm{i}$ rozwoju larw w orzechach. W lipcu chrząszcze chętniej i częściej żerowały na orzechach odmian wrażliwych, natomiast unikały ich $w$ sierpniu, tj. w okresie, gdy w wielu orzechach tych odmian rozwijały się larwy. W pracy przedyskutowano przypuszczalny mechanizm tego zjawiska. 